\title{
Analisis Faktor-Faktor Yang Mempengaruhi Keuntungan Kontraktor pada Proyek Konstruksi Gedung di Kota Padang 2018
}

\author{
Riswandi ${ }^{1}$, Monika Natalia ${ }^{2}$, Satwarnirat ${ }^{3}$, Zulfira Mirani ${ }^{4}$, Muhammad Laila Sapril ${ }^{5}$ \\ 1,2,3,4,5 Jurusan Teknik Sipil, Politeknik Negeri Padang \\ Email : riswandi@yahoo.com, monikanatalia75@gmail.com, Satwarnirat1966@gmail.com, \\ zulfiramirani@yahoo.com
}

\begin{abstract}
Abstrak
Suatu proyek dikatakan sukses apabila minimal memenuhi empat faktor, antara lain adalah proyek berjalan sesuai jadwal kontrak, mendapatkan keuntungan karena pengeluaran sesuai dengan yang direncanakan, masalah yang terjadi dalam proyek kecil, dan tidak terjadi kecelakaan kerja. Jika teknis yang digunakan kurang baik maka akan berdampak buruk pada kinerja proyek dan dapat menimbulkan kerugian terutama kerugian dari segi biaya. Kerugian dari segi biaya ini akan mengurangi keuntungan dari kontraktor.

Laba atau keuntungan merupakan salah satu tujuan utama perusahaan dalam menjalankan aktivitasnya. Laba yang diperoleh perusahaan akan digunakan untuk berbagai kepentingan, laba akan digunakan untuk meningkatkan kesejahteraan perusahaan tersebut atas jasa yang diperolehnya. Tujuan dari penelitian ini adalah untuk mengetahui faktor apa saja yang mempengaruhi keuntungan pada proyek konstruksi gedung di kota Padang. Kuesinoer disebarkan ke 11 perusahaan kontraktor yang memiliki kualifikasi M2 di kota Padang.

Metode analisis data yang akan digunakan adalah uji validitas, uji realibilitas, uji korelasi dan analisis deskriptif yang dioperasikan dengan menggunakan program SPSS ver.24. Hasil analisis menunjukan yang sangat mempengaruhi keuntungan kontraktor yaitu pada faktor tenaga kerja dengan subfaktor kurang teliti dalam penggunaan material, sehingga ada material konstruksi yang terpasang tidak sesuai dengan rencana. Hal ini dibuktikan dengan nilai mean sebesar 4,77 atau 95,4\% dengan nilai signifikasi sebesar 0,004 dan tingkat hubunganya (korelasi) sebesar 0,582 (kuat).
\end{abstract}

Kata kunci: keuntungan, kontraktor, SPSS ver.24, proyek gedung kota padang

\section{PENDAHULUAN}

Suatu proyek dikatakan sukses apabila minimal memenuhi empat faktor, antara lain adalah proyek berjalan sesuai jadwal kontrak, mendapatkan keuntungan karena pengeluaran sesuai dengan yang direncanakan, masalah yang terjadi dalam proyek kecil, dan tidak terjadi kecelakaan kerja. Jika teknis yang digunakan kurang baik maka akan berdampak buruk pada kinerja proyek dan dapat menimbulkan kerugian terutama kerugian dari segi biaya. Kerugian dari segi biaya ini akan mengurangi keuntungandari kontraktor.

$$
\text { Profitbilitas atau kemampuan }
$$

memperoleh laba adalah suatu ukuran dalam persentase yang digunakan unutk menilai sejauh mana perusahaan mampu menghasilkan laba pada tingkat yang dapat diterima. Laba (income) menurut Nafarin (2007 : 788) adalah perbedaan antara pendapatan dengan keseimbangan biaya-biaya dan pengeluaran untuk periode tertentu.

Laba atau keuntungan merupakan salah satu tujuan utama perusahaan dalam menjalankan aktivitasnya. Laba yang diperoleh perusahaan akan digunakan untuk berbagai kepentingan, laba akan digunakan untuk meningkatkan kesejahteraan perusahaan tersebut atas jasa yang diperolehnya. 
Bisnis konstruksi merupakan bisnis dengan kompleksitas yang sangat tinggi yang demikian memiliki risiko yang tinggi pula. Akibatnya bisnis ini pada dasarnya sulit untuk mendapatkan keuntungan yang besar. Net keuntungan margin bisnis ini sangatlah kecil, yaitu berkisar sekitar $2 \%$ - 4\%. Sehingga untuk menopang target laba, perusahaan konstruksi harus memacu produksi yang lebih tinggi.

Jika diperhatikan, bahwa perusahaan konstruksi umumya memasang target laba bersih pada setiap proyek yang ditenderkan adalah berkisar diangka $4 \%-12 \%$ terhadap nilai kontrak dan yang paling sering adalah dikisaran angka $7 \%$ - 9\% atau rata2 $8 \%$. Namun kenyataannya angka tersebut bergeser saat laporan proyek selesai atau proyek mengalami pengurangan laba hingga mengalami kerugian. Menurut pengamatan angka sering menjadi 5\%-6\%. angka ini lalu setelah dikurangi dengan overhead kantor pusat dan beban biaya lainnya akan menjadi 2\%- 4\% saja.

Padahal dengan tingkat kompleksitasnya yang sangat tinggi, membuat karyawan perusahaan konstruksi bekerja siang-malam demi mengejar target proyek yang seringkali begitu ketat. Kadang mereka juga terlibat konflik dengan pada vendor maupun Owner dalam rangka menjaga target keuntungan proyek.

Dari uraian diatas maka penulis memilih judul "Analisis Faktor-Faktor Yang Mempengaruhi KeuntunganKontraktor M2 Pada Proyek Konstruksi Gedung Di Kota Padang 2018".
Tujuan Penelitian

- Untuk mengetahui faktor apa saja yang mempengaruhi keuntungan pada proyek konstruksi gedung di kota Padang.

- Untuk mengetahui faktor dominan apa saja yang mempengaruhi keuntungan kontraktor pada proyek konstruksi gedung di kota Padang.

- Untuk mengetahui seberapa besar faktor dominan dalam mempengaruhi keuntungan kontraktor pada proyek konstruksi gedung di kota Padang

\section{Perencanaan Biaya Proyek}

Perencanaan biaya untuk suatu proyek adalah prakiraan keuangan yang merupakan dasar untuk pengendalian biaya proyek serta aliran kas proyek tersebut. Pengembangan dari hal tersebut diantaranya adalah fungsi dari estimasi biaya, anggaran, aliran kas, pengendalian biaya, dan keuntungan proyek tersebut (Chandra, et al., 2003). Estimasi biaya konstruksi memberikan indikasi utama yang spesifik dari total biaya proyek konstruksi. Estimasi biaya (cost estimate) digunakan untuk mencapai suatu harga kontrak sesuai persetujuan antara pemilik proyek dengan kontraktor, menentukan anggaran, dan sekaligus mengendalikan biaya proyek.

\section{Estimasi Biaya}

Salah satu hal penting dalam pembuatan proposal proyek adalah estimasi dan penganggaran. Penting karena jika estimasi biaya dilakukan dengan dengan kurang hatihati sehingga menghasilkan perkiraan biaya yang terlalu tinggi, maka akan berakibat perusahaan akan kalah bersaing dengan perusahaan lain yang menawarkan harga lebih rendah dengan kualitas yang 
JIRS Volume XVI Nomor 1, April 2019

sepadan. Sebaliknya bila estimasi biaya yang dilakukan ternyata terlalu rendah, maka meski menang dalam tender namun dalam pelaksanaannya dapat mengalami kesulitan pendanaan yang dapat berujung pada tidak selesainya proyek dan kehilangan kepercayaan dari mereka yang memberi proyek.

\section{Keuntungan}

Laba (income) menurut Nafarin (2007:788) adalah perbedaan antara pendappatan dengan keseimbangan biaya-biaya dan pengeluaran untuk periode tertentu. Menurut Abdul Halim dan Bambang Supomo (2005:139), Laba merupakan pusat pertanggung jawaban yang masukan dan keluarannya diukur dengan menghitung selisih antara pendapatan dan biaya.

\section{Indikator-indikator dalam menghitung keuntungan}

- Keuntungan margin, yaitu persentase perbandingan dengan omzet yang diterima.

Rumus laba atau keuntungan :

Laba = Omzet - Biaya bahan baku (termasuk ongkos kerja) - Biaya adm

- Return On Investment (ROI) atau juga biasa ditulis tingkat pengembalian atas investasi, yaitu berapa modal yang digunakan dan berapa persentase keuntungan atau laba yang didapatkannya.

- Break Even Point (BEP) atau juga biasa disebut dengan tittik impas, yaitu seluruh biaya yang dikeluarkan ter-cover atau terlunasi dari omzet yang didapat, sehingga keuntunganya nol. Baru omzet selanjutnya dihitung sebagai keuntingan atau laba.

- Payback Period, yaitu perhitungan waktu yang dibutuhkan untuk modal investasi yang telah digunakan ter-cover sepenuhnya alias kembali seutuhnya. Jadi misalnya
e-ISSN : 2655-2124 / ISSN : 1858-3695

dalam perhitungan payback period ini membutuhkan waktu 12 bulan untuk balik modal, maka omzet dari bulan ke 13 dan seterusnya adalah keuntunganya.

\section{Faktor-faktor yang mempengaruhi keuntungan}

- Faktor tenaga kerja

Tenaga Kerja merupakan salah satu unsur penting dalam pelaksanaan suatu proyek karena pengaruhnya yang cukup besar terhadap biaya dan waktu penyelesaian suatu pekerjaan proyek. Namun perlu diperhatikan juga bahwa manusia merupakan sumber daya yang komplek dan sulit diprediksi sehingga diperlukan adanya usaha dan pemikiran lebih mendalam dalam pengelolaan tenaga kerja.

- Faktor material

Pada setiap proyek konstruksi, pengadaan material merupakan bagian terpenting, karena sumber daya material dapat menyerap 50\%-70\% dari biaya proyek (Ervianto, 2004). Oleh karena itu, pengguna teknik manajemen yang baik dan tepat untuk membeli, menyimpan, mendistribusikan dan menghitung material konstruksi menjadi sangat penting agar aliran material pada proyek dapat berjalan lancar.

Penyimpanan bahan-bahan bangunan perlu mendapat perhatian khusus, mengingat bahan yang sangat peka terhadap kondisi lingkungan, seperti semen dan tulangan yang sangat dipengaruhi oleh air dan udara. Penempatan bahan yang tepat dan seefesien mungkin juga perlu diperhatikan untuk dapat mempercepat dan mempermudah pekerjaan. Di samping itu , penempatan bahan yang baik dan tertata rapi akan mendukung efektifitas kerja dan 


keselamatan kerja. Pengaturan

penyimpanan bahan-bahan bangunan dan peralatan pada suatu proyek menjadi tanggung jawab bagian logistik (material management) dan gudang (warehouse).

\section{- Faktor peralatan}

Peralatan kerja yang digunakan terdiri dari alat-alat berat dan alat-alat pelengakap lainya. Baik yang digerakan secara manual atau mekanis. Pemilihan jenis peralatan yang akan digunakan dalam suatu pekerjaan merupakan faktor penting yang mempengaruhi proses penyelesaian suatu pekerjaan secara cepat dan tepat. Pertimbangan dari segi biaya sehubungan dengan penggunaan peralatan harus tetap ada, artinya harus ada optimasi dari harga produksi per satuan waktu untuk setiap peralatan yang digunakan. Selama pelaksanaan pekerjaan di proyek, pemeliharaan dan perawatan peralatan terutama untuk alat-alat berat harus dilakukan secara rutin, sehingga kondisi alat selalu baik dan siap pakai. Hal ini sangat penting agar dalam pelaksanaan nanti tidak terhambat karena adanya kerusakan pada peralatan kerja.

- Faktor karakeristik lapangan

Strategi yang tepat akan dapat mengatasi setiap masalah karakteristik lapangan yang timbul, oleh karena itu survey lapangan perlu dilakukan terlebih dahlu sebelum pekerjaan pembangunan proyek dilaksanakan seperti conttoh perkiraan pemeriksaan keadaan tanah dan bawah tanah lapangan (Walker, 1994).

- Faktor Keuangan

Pada bagian ini faktor-faktor yang disebutkan lebih cedrung mempengaruhi keuntungan kontaktor pembangunan proyek dari sisi pemiliknya lebih dari satu

orang dibandingkan dengan pemilik proyek bangunan pribadi yang berkali-kali membangun proyek akan mengalami keterllambatan pembayaran yang lebih buruk. (Sidwell :1982, Prajogo dan Klemens:1996)

- Metode Pelaksanaan

Dalam pelaksanaan pekerjaan konstruksi, ada kalanya diperlukan suatu metode terobosan untuk menyelesaikan berbagai masalah di lapangan. Khususnya pada saat-saat menghadapi kendala yang diakibatkan oleh kondisi di lapangan yang tidak sesuai dengan dugaan sebelumnya. Untuk itu, penerapan metode pelaksanaan kontruksi yang sesuai kondisi lapangan, akan sangat membantu dalam penyelesaian proyek konstruksi bersangkutan.

Tabel 1. Faktor dan subfaktor yang mempengaruhi keuntungan kontraktor pada proyek konstruksi gedung dikota Padang

\begin{tabular}{|c|c|l|}
\hline $\mathrm{N}$ & Faktor- & \multicolumn{1}{|c|}{$\begin{array}{c}\text { Sub faktor yang } \\
\text { mempengaruhi } \\
\text { keuntungankontraktor } \\
\text { faktor } \\
\text { pada proyek konstruksi di } \\
\text { kota Padang. }\end{array}$} \\
\hline \multirow{5}{*}{1} & $\begin{array}{l}\text { Fluktuasiupah tenaga } \\
\text { kerja yang tinggi }\end{array}$ \\
& $\begin{array}{l}\text { Tenagangna pengawasan } \\
\text { Kerja } \\
\text { terhadap tenaga kerja } \\
\text { sehingga produktivitas } \\
\text { tenaga kerja rendah. }\end{array}$ \\
& $\begin{array}{l}\text { Kurang teliti dalam } \\
\text { penggunaan material, } \\
\text { sehingga ada material } \\
\text { konstruksi yang } \\
\text { terpasang tidak sesuai } \\
\text { dengan rencana. } \\
\text { Contoh : Adukan atau } \\
\text { Campuran dari beton } \\
\text { tidak sesuai dengan } \\
\text { rencana mutu beton } \\
\text { sehingga menyebabkan }\end{array}$ \\
\hline
\end{tabular}




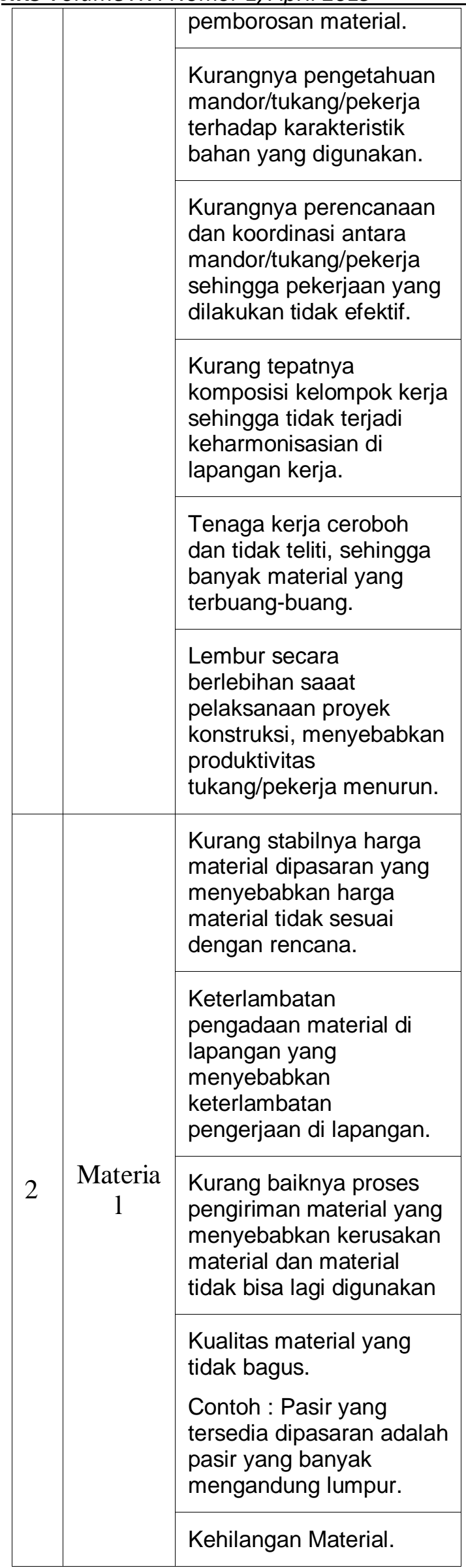

\begin{tabular}{|c|c|c|}
\hline & & $\begin{array}{l}\text { Contohnya : Proses } \\
\text { pengerjaan pemotongan } \\
\text { besi yang tidak baik yang } \\
\text { menyebabkan banyak } \\
\text { sisa-sisa pemotongan } \\
\text { besi yang tidak bisa } \\
\text { dipakai. }\end{array}$ \\
\hline & & $\begin{array}{l}\text { Keterbatasan gudang } \\
\text { penyimpanan yang } \\
\text { menyebabkan tidak bisa } \\
\text { membeli material dalam } \\
\text { jumlah yang banyak. }\end{array}$ \\
\hline & & $\begin{array}{l}\text { Kelangkaan material di } \\
\text { pasaran. }\end{array}$ \\
\hline & & $\begin{array}{l}\text { Contoh : Ketika musim } \\
\text { hujan sangat sulit untuk } \\
\text { mendapatkan pasir dan } \\
\text { kerikil dikarenakan debit } \\
\text { air yang besar di sungai. }\end{array}$ \\
\hline & & $\begin{array}{l}\text { Tipe dan ukuran } \\
\text { peralatan yang sesuai } \\
\text { dengan yang dibutuhkan } \\
\text { di lapangan. }\end{array}$ \\
\hline & & $\begin{array}{l}\text { Kurangnya optimalnya } \\
\text { penjadwalan peralatan } \\
\text { yang digunakan sehingga } \\
\text { mengakibatkan peralatan } \\
\text { menggagur dalam jangka } \\
\text { waktu yang cukup lama. }\end{array}$ \\
\hline 3 & $\begin{array}{l}\text { Peralata } \\
\mathrm{n}\end{array}$ & $\begin{array}{l}\text { Penggunaan peralatan } \\
\text { yang jarang dirawat } \\
\text { atau peralatan yang } \\
\text { digunakan dalam } \\
\text { keadaan tidak prima. }\end{array}$ \\
\hline & & $\begin{array}{l}\text { Kurang tepatnya } \\
\text { keputasan dalam } \\
\text { memilih membeli atau } \\
\text { menyewa peralatan. }\end{array}$ \\
\hline & & $\begin{array}{l}\text { Penggunaan peralatan- } \\
\text { peralatan baru yang } \\
\text { kurang dikenal oleh } \\
\text { operator. }\end{array}$ \\
\hline 4 & $\begin{array}{c}\text { Metode } \\
\text { Pelaksa } \\
\text { naan }\end{array}$ & $\begin{array}{l}\text { Kurang tepatnya } \\
\text { pemilihan antara } \\
\text { penggunaan alat berat } \\
\text { atau tenaga manusia }\end{array}$ \\
\hline & & $\begin{array}{l}\text { Contoh : pada pekerjaan } \\
\text { perataan dan penggalian }\end{array}$ \\
\hline
\end{tabular}




\begin{tabular}{|c|c|c|}
\hline & & tanah. \\
\hline & & $\begin{array}{l}\text { Kurang tepatnya } \\
\text { pemilihan metode } \\
\text { pelaksanaan dalam } \\
\text { menghadapi suatu } \\
\text { masalah pada proyek } \\
\text { konstruksi }\end{array}$ \\
\hline & & $\begin{array}{l}\text { Kurang baiknya kondisi } \\
\text { lapangan sehingga } \\
\text { menyebabkan metode } \\
\text { pelaksanaan tidak sesuai } \\
\text { dengan rencana. }\end{array}$ \\
\hline & & $\begin{array}{l}\text { Contoh : dalam } \\
\text { pemakaian alat berat } \\
\text { yang dibutuhkan adalah } \\
\text { alat berat dengan ukuran } \\
\text { besar karena akses jala } \\
\text { masuk menuju proyek } \\
\text { kecil sehingga haya } \\
\text { memungkin untuk } \\
\text { memakai alat berat } \\
\text { dengan ukuran yang lebih } \\
\text { kecil. }\end{array}$ \\
\hline & & $\begin{array}{l}\text { Kurang tepatnya } \\
\text { pemakaian metode } \\
\text { pelaksanaan pada } \\
\text { konstrusi }\end{array}$ \\
\hline & & $\begin{array}{l}\text { Kelemahan dalam } \\
\text { perencanaan logistik }\end{array}$ \\
\hline & Keuang & $\begin{array}{l}\text { Kurang tepatnya } \\
\text { pemilihan sistem } \\
\text { pengajian antara } \\
\text { borongan atau gaji harian } \\
\text { kepada tukang/pekerja }\end{array}$ \\
\hline & & $\begin{array}{l}\text { Keterlambatan pencairan } \\
\text { dana atau termyn yang } \\
\text { mengakibatkan pemimpin } \\
\text { proyek harus berhutang. }\end{array}$ \\
\hline & & $\begin{array}{l}\text { Kurangnya modal di } \\
\text { tahap awal memulai } \\
\text { suatu proyek konstruksi. }\end{array}$ \\
\hline 6 & $\begin{array}{l}\text { Karakter } \\
\text { istik } \\
\text { lapanga }\end{array}$ & $\begin{array}{l}\text { Kerusakan lingkungan } \\
\text { akibat adanya proyek } \\
\text { sehingga ada beberapa } \\
\text { pihak yang komplain dan } \\
\text { meminta ganti rugi. }\end{array}$ \\
\hline & $n$ & $\begin{array}{l}\text { Respon masyarakat yang } \\
\text { kurang mendukung } \\
\text { adanya proyek }\end{array}$ \\
\hline
\end{tabular}

\begin{tabular}{|l|l|}
\hline \multirow{2}{*}{} & $\begin{array}{l}\text { Contoh : Kesulitan ketika } \\
\text { pembebasan lahan dan } \\
\text { kesulitan untuk meminta } \\
\text { akses jalan masuk ke } \\
\text { dalam proyek. }\end{array}$ \\
\cline { 2 - 2 } & $\begin{array}{l}\text { Lingkungan proyek yang } \\
\text { tidak aman. } \\
\text { Contoh : aksi } \\
\text { premanisme, pencurian } \\
\text { material dan lain-lain. }\end{array}$ \\
\cline { 2 - 2 } & Terjadi hura-hura \\
\hline
\end{tabular}

Analisis Data Dengan SPSS (Statistical

\section{Product Solution Service)}

SPSS adalah salah satu program yang paling banyak digunakan untuk analisis statistika. Pengolahan data pada penelitian tugas akhir ini, penulis menggunakan SPSS versi 24 .

\section{Uji Validitas}

Suatu dimensi atau indikator dikatakan valid apabila indikator tersebut mampu mencapai tujuan pengukuran dari variabel pengamatan $A$ haruslah indikator yang pada akhirnya memberikan informasi dan menggambarkan variabel pengamatan A. Dalam praktiknya, kecermatan pengukuran baik dalam bidang eksak, sosial ataupun psikologi yang masih didapati suatu kesalahan. Kesalahan itu dapat berupa hasil yang terlalu tinggi (overestimate) atau terlalu rendah (underestimate). Kesalahan-kesalahan inilah yang disebut dengan istilah measurement error. Indikator yang valid adalah indikator yang memiliki tingkat mesurement error yang kecil.

\section{Uji Reliabilitas}

Uji reliabilitas merupakan terjemahan dari realibility yang berasal dari kata real dan ability. Reliabilitas biasa diartikan sebagai keterpecayaan, keterandalan atau konsistensi. Hasil suatu pengukuran dapat dipercaya apabila dalam beberapa kali pelaksanaan 
pengukuran terhadap subjek yang sama diperoleh data yang relatif sama, artinya mempunyai konsistensi pengukuran yang baik. Sebaliknya, apabila diperoleh suatu hasil yang berbeda-beda dengan subjek yang sama, maka dikatakan inkonsisten.

\section{Uji Korelasi}

Korelasi merupakan salah satu statistik infarensi yang akan menguji dua variabel atau lebih yang mempunyai hubungan atau tidak. Uji korelasi bertujuan untuk menguji hubungan antara dua variabel dapat dilihat dengan tingkat signifikan, jika ada hubungannya maka dicari seberapa kuat hubungan tersebut. Keeratan hubungan ini dinyatakan dalam bentuk koefisien korelasi di mana dengan uji ini akan mengembalikan nilai koefisien korelasi yang nilainya berkisar antara $-1,0$ dan 1 . Nilai 1 artinya terdapat korelasi negatif yang sempurna, 0 artinya tidak ada korelasi dan nilai 1 berarti ada korelasi positif yang sempurna. Rentang dari koefisien korelasi yang berkisar antara -1, 0 dan 1 tersebut dapat disimpulkan bahwa apabila semakin mendekati nilai 1 atau -1 maka hubungan makin erat, sedangkan jika semakin mendekati 0 maka hubungan semakin lemah. Tabel 2.1 menjelaskan interpretasi nilai koefisien korelasi.

\section{Metode Penelitian}

\section{Diagram Alir Penelitian}

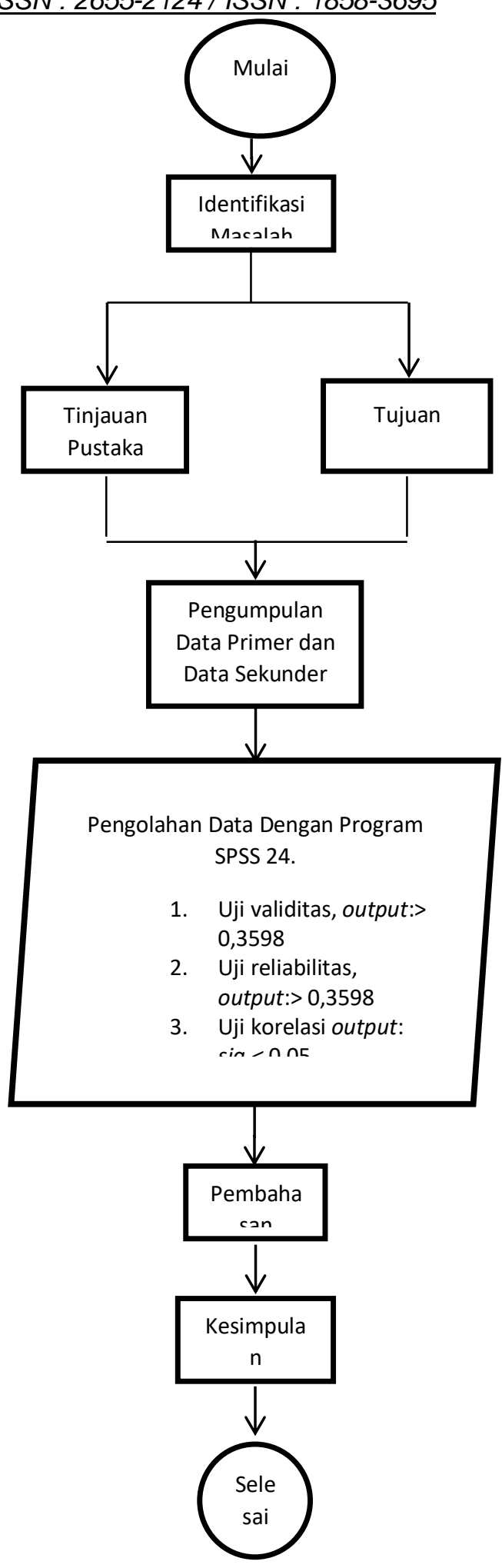




\section{Objek Penelitian}

Penelitian ini dilakukan pada kontraktor yang memiliki kantor pusat atau kantor cabang di kota Padang yang telah atau sedang melaksanakan proyek konstruksi gedung dalam kurun waktu 10 tahun terakhir (20082018) yang tergabung dalam anggota GAPENSI (Gabungan Pelaksana Konstruksi Nasional Indonesia).

\section{Penentuan Populasi dan Sampel}

Pada penelitian ini, populasi merupakan kontraktor yang memiliki kua-lifikasi M1 atau M2 pada tahun 2018. Sedangkan sampel penelitian adalah pihak yang terlibat pada kontraktor pelaksana proyek konstruksi, meliputi project manager dan site manager.

\section{Data Penelitian}

Data yang akan diteliti dan dianalisis dalam penelitian ini terdiri dari 2 (dua) data, yaitu data primer dan data sekunder:

- Data Sekunder

Data sekunder didapat dari studi literatur dan Penelitian-penelitian terdahulu akan menjadi sumber referensi penulis untuk membuat tinjauan pustaka pada bab 2 , yaitu tentang faktor-faktor yang mempengaruhi keuntungan kontraktor pada proyek konstruksi gedung di kota Padang. Data sekunder juga didapat dari kantor GAPENSI yaitu daftar nama kontraktor gedung yang tergabung dalam anggota GAPENSI 2018 yang memiliki kualifikasi M1 atau M2.

- Data Primer

Data primer didapat dari kuesioner berisi daftar pertanyaan yang akan dijawab oleh responden. Pertanyaan-pertanyaan di dalam kuesioner berisi-kan faktor-faktor yang mempengaruhi keuntungan kontraktor pada proyek konstruksi gedung di kota
e-ISSN : 2655-2124 / ISSN : 1858-3695

Padang, yang ditempatkan dalam kuesioner. Bagian kanan berisi kolom cheklist yang akan diisi oleh responden untuk menjawab setiap pertanyaan.

Skala penilaian yang akan digunakan penulis untuk menyusun pertanyaan questionnaire nantinya adalah dengan skala Likert dimana responden diberi pilihan (option) yang kemudian tinggal memilih derajat keseringan/jarang (terjadi) atas pernyataan yang diajukan. (Sugiyono, 2012).

Adapun skala penilaian yang dimaksud adalah sebagai berikut:

Skor 5 = Sangat Sering(kemungkinan terjadi antara $81 \%-100 \%$ )

Skor $4=$ Sering (kemungkinan terjadi antara $61 \%-80 \%)$

Skor $3=$ Kadang-kadang(kemungkinan terjadi antara $41 \%$ - 60\%)

Skor $2=$ Jarang(kemungkinan terjadi antara $21 \%$ - 40\%)

Skor 1 = Sangat Jarang(kemungkinan terjadi antara 0\% - 20\%)

\section{Hasil Penelitian}

Lokasi pengambilan data dilakukan pada perusahaan-perusahaan penyedia jasa konstruksi gedung di kota padang yang tergabung dalam anggota GAPENSI (Gabungan Pelaksana Konstruksi Nasional Indonesia) dengan kualifikasi M2 baik proyek yang dimilik pemerintah maupun swasta.

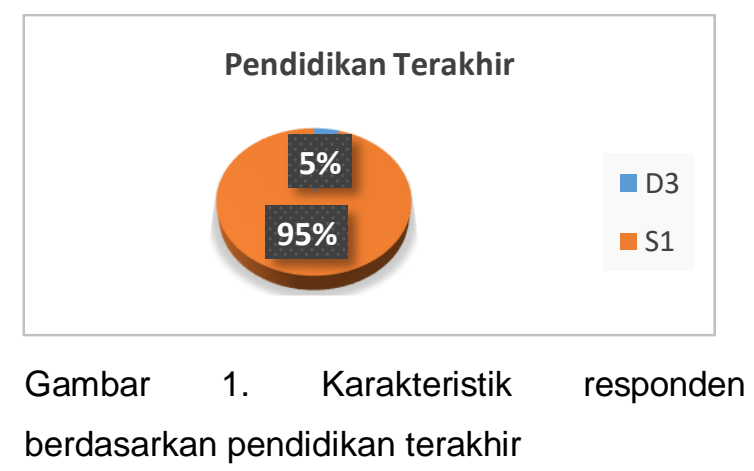




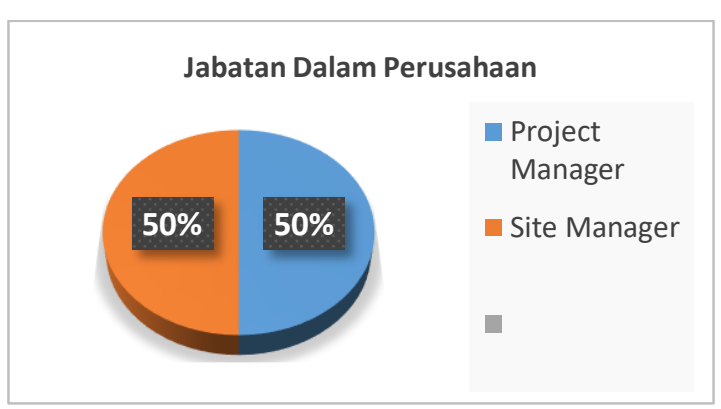

Gambar 2. Karakteristik responden berdasarkan jabatan dalam perusahaan

Pengalaman Bekerja Sebagai Project Manager

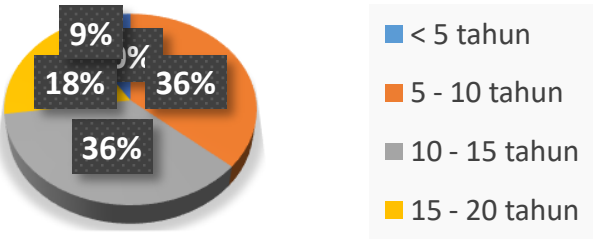

Gambar 3. Karakteristik responden berdasarkan pengalaman bekerja sebagai prject manager

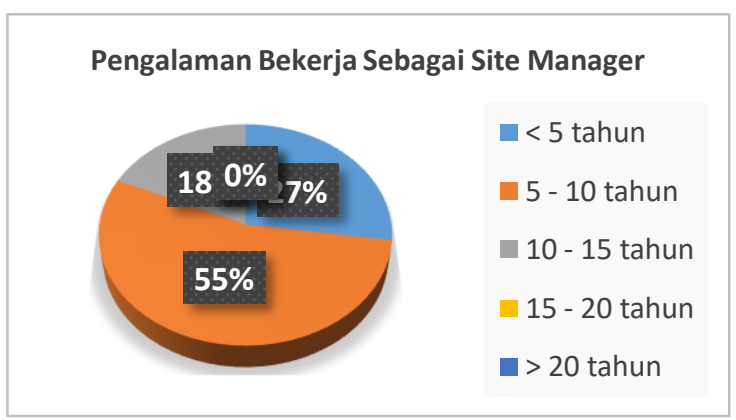

Gambar 4.Karakteristik responden berdasarkan pengalaman bekerja sebagai site manager

\section{Uji Validitas}

Tabel 2. Hasil Pengujian Faktor Tenaga Kerja $\left(\mathrm{X}_{1}\right)$

\begin{tabular}{|c|c|c|c|}
\hline Variabel & $\begin{array}{c}r \\
\text { hitung }\end{array}$ & $\begin{array}{c}r \\
\text { tabel }\end{array}$ & Keterangan \\
\hline $\mathrm{X} 1.1$ & 0,800 & $\begin{array}{c}> \\
0,359\end{array}$ & Valid \\
\hline $\mathrm{X} 1.2$ & 0,771 & $\begin{array}{c}> \\
0,359\end{array}$ & Valid \\
\hline $\mathrm{X} 1.3$ & 0,775 & $>$ & Valid \\
\hline
\end{tabular}

\begin{tabular}{|c|c|c|c|}
\hline \hline X1.4 & 0,748 & $\begin{array}{c}> \\
0,359\end{array}$ & Valid \\
\hline X1.5 & 0,725 & $\begin{array}{c}> \\
0,359\end{array}$ & Valid \\
\hline X1.6 & 0,767 & $\begin{array}{c}> \\
0,359\end{array}$ & Valid \\
\hline X1.7 & 0,759 & $\begin{array}{c}> \\
0,359\end{array}$ & Valid \\
\hline X1.8 & 0,782 & $\begin{array}{c}> \\
0,359\end{array}$ & Valid \\
\hline
\end{tabular}

Tabel 3. Hasil Pengujian Faktor Material $\left(\mathrm{X}_{2}\right)$

\begin{tabular}{|c|c|c|c|}
\hline Variabel & $r$ hitung & $r$ tabel & Keterangan \\
\hline X2.1 & 0,808 & $>0,359$ & Valid \\
\hline X2.2 & 0,815 & $>0,359$ & Valid \\
\hline X2.3 & 0,765 & $>0,359$ & Valid \\
\hline X2.4 & 0,764 & $>0,359$ & Valid \\
\hline X2.5 & 0,807 & $>0,359$ & Valid \\
\hline X2.6 & 0,801 & $>0,359$ & Valid \\
\hline X2.7 & 0,813 & $>0,359$ & Valid \\
\hline
\end{tabular}

Sumber : Hasil analisa SPSS Versi 24

Tabel 4. Hasil Pengujian Faktor Peralatan ( $\left.X_{3}\right)$

\begin{tabular}{|l|l|l|c|}
\hline Variabel & r hitung & r tabel & Keterangan \\
\hline X3.1 & 0,705 & $>0,359$ & Valid \\
\hline X3.2 & 0,643 & $>0,359$ & Valid \\
\hline X3.3 & 0,646 & $>0,359$ & Valid \\
\hline X3.4 & 0,682 & $>0,359$ & Valid \\
\hline X3.5 & 0,636 & $>0,359$ & Valid \\
\hline
\end{tabular}

Sumber: Hasil analisa SPSS Versi 24

Tabel 5. Hasil Pengujian Faktor Metode Pelaksanaan $\left(\mathrm{X}_{4}\right)$

\begin{tabular}{|r|c|c|c|}
\hline Variabel & r hitung & $r$ tabel & Keterangan \\
\hline $\mathrm{X} 4.1$ & 0,548 & $>0,359$ & Valid \\
\hline $\mathrm{X} 4.2$ & 0,561 & $>0,359$ & Valid \\
\hline $\mathrm{X} 4.3$ & 0,681 & $>0,359$ & Valid \\
\hline $\mathrm{X} 4.4$ & 0,663 & $>0,359$ & Valid \\
\hline
\end{tabular}

Sumber : Hasil analisa SPSS Versi 24

Tabel 6. Hasil Pengujian Faktor Keuangan ( $\left.X_{5}\right)$ \begin{tabular}{|l|l|l|l|}
\hline Variabel & $r$ hitung & $r$ tabel & Keterangan \\
\hline
\end{tabular} 
JIRS Volume XVI Nomor 1, April 2019

\begin{tabular}{|l|l|l|l|}
\hline \hline X5.1 & 0,680 & $>0,359$ & Valid \\
\hline X5.2 & 0,658 & $>0,359$ & Valid \\
\hline X5.3 & 0,768 & $>0,359$ & Valid \\
\hline X5.4 & 0,624 & $>0,359$ & Valid \\
\hline
\end{tabular}

Sumber : Hasil analisa SPSS Versi 24

Tabel 7. Hasil Pengujian Faktor Karakteristik Lapangan (X6)

\begin{tabular}{|r|r|r|c|}
\hline Variabel & $r$ hitung & $\begin{array}{r}r \\
\text { tabel }\end{array}$ & Keterangan \\
\hline $\mathrm{X} 6.1$ & 0,608 & $>0,3598$ & Valid \\
\hline $\mathrm{X} 6.2$ & 0,725 & $>0,3598$ & Valid \\
\hline $\mathrm{X} 6.3$ & 0,636 & $>0,3598$ & Valid \\
\hline $\mathrm{X} 6.4$ & 0,766 & $>0,3598$ & Valid \\
\hline
\end{tabular}

Sumber : Hasil analisa SPSS Versi 24

\section{Uji Reliabilitas}

Reliabilitas menunjukkan suatu pengertian bahwa suatu instrumen dapat dipercaya (Arikunto, 2010). Uji reliabilitas yang dimaksud penelitian ini adalah untuk mengetahui kekonsistenan jawaban seseorang terhadap pernyataan dari waktu ke waktu. Untuk mengukur reliabilitas dari waktu ke waktu maka digunakan rumus cronbach alphayang diolah dengan program SPSS versi 24.

Kriteria pengujian ini adalah jika nilai koefisien cronbach alpha $\left(r_{11}\right)>0.90$ maka reliabilitas sempurna. Jika alpha antara 0.70-0.90 maka reliabilitas dikatakan tinggi. Jika alpha antara 0.50-0.70 maka reliabilitas moderat/sedang. Jika alpha $<0.50$ maka reliabilitas rendah. Jika alpha rendah, kemungkinan satu atau beberapa item tidak reliable.

Tabel 8. Hasil Uji Reliabilitas

\begin{tabular}{|c|l|c|c|}
\hline $\begin{array}{c}\mathbf{N} \\
\mathbf{0}\end{array}$ & Variabel & $\begin{array}{c}\text { Cronbac } \\
\boldsymbol{h} \text { Alpha }\end{array}$ & $\begin{array}{c}\text { Keteranga } \\
\mathbf{n}\end{array}$ \\
\hline 1 & $\begin{array}{l}\text { (X1) Faktor } \\
\text { Tenaga } \\
\text { Kerja }\end{array}$ & 0,790 & Tinggi \\
\hline
\end{tabular}

e-ISSN : 2655-2124 / ISSN : 1858-3695

\begin{tabular}{|r|l|c|l|}
\hline 2 & $\begin{array}{l}\text { (X2) Faktor } \\
\text { Material }\end{array}$ & 0,821 & Tinggi \\
\hline 3 & $\begin{array}{l}\text { (X3) Faktor } \\
\text { Peralatan }\end{array}$ & 0,710 & Tinggi \\
\hline 4 & $\begin{array}{l}\text { (X4) Faktor } \\
\text { Metode } \\
\text { Pelaksanaa } \\
\text { n }\end{array}$ & 0,687 & Sedang \\
\hline 5 & $\begin{array}{l}\text { (X5) Faktor } \\
\text { Keuangan }\end{array}$ & 0,742 & Tinggi \\
\hline 6 & $\begin{array}{l}\text { (X6) Faktor } \\
\text { Karakteristi } \\
\text { k Lapangan }\end{array}$ & 0,746 & Tinggi \\
\hline
\end{tabular}

Sumber : Hasil analisa SPSS Versi 24

\section{Uji Korelasi}

Tabel 9. Klasifikasi Nilai Koefisien Korelasi $r$ Pearson

\begin{tabular}{||c|c|}
\hline $\begin{array}{c}\text { Interval } \\
\text { Koefisien }\end{array}$ & Tingkat Hubungan \\
\hline $0.80-1.000$ & Sangat kuat \\
\hline $0.60-0.799$ & Kuat \\
\hline $0.40-0.599$ & Cukup Kuat \\
\hline $0.20-0.399$ & Rendah \\
\hline $0.00-0.199$ & Sangat Rendah \\
\hline
\end{tabular}

Sumber : Anwar Hidayat, Juli 2012

Ada dua cara untuk pengambilan keputusan dalam analisis korelasi yakni dengan melihat nilai signifikansi dan tanda bintang yang diberikan pada output program SPSS.

- Berdasarkan nilai signifikansi: jika nilai signifikansi $<0,05$ maka terdapat korelasi, sebaliknya jika nilai signifikansi $>0,05$ maka tidak terdapat korelasi.

- Berdasarkan tanda bintang $\left(^{*}\right)$ yang diberikan SPSS: jika terdapat tanda bintang pada pearson correlation maka antara variabel yang dianalisis terjadi korelasi, sebaliknya jika tidak terdapat tanda bintang pada pearson correlation maka antara variabel yang dianalisis tidak terjadi korelasi. 
JIRS Volume XVI Nomor 1, April 2019

e-ISSN : 2655-2124 / ISSN : 1858-3695

Tabel 10. Hasil Rekapitulasi Analisa Korelasi Person Product Moment

\begin{tabular}{|c|c|c|c|}
\hline No & Variabel & Nilai Koefisien Korelasi & Tingkat Hubungan \\
\hline 1 & $\mathrm{X} 1.1$ & $-0,275$ & Tidak Ada Hubungan \\
\hline 2 & $\mathrm{X} 1.2$ & 0,105 & Sangat Lemah \\
\hline 3 & $\mathrm{X} 1.3$ & 0,582 & Cukup Erat \\
\hline 4 & $\mathrm{X} 1.4$ & $-0,151$ & Tidak Ada Hubungan \\
\hline 5 & $\mathrm{X} 1.5$ & $-0,115$ & Tidak Ada Hubungan \\
\hline 6 & $\mathrm{X} 1.6$ & 0,222 & Rendah \\
\hline 7 & $\mathrm{X} 1.7$ & 0,418 & Cukup Erat \\
\hline 8 & $\mathrm{X} 1.8$ & 0,362 & Rendah \\
\hline 9 & $\mathrm{X} 2.1$ & 0,000 & Tidak Ada Hubungan \\
\hline 10 & $\mathrm{X} 2.2$ & 0,105 & Sangat Lemah \\
\hline 11 & $\mathrm{X} 2.3$ & 0,000 & Tidak Ada Hubungan \\
\hline 12 & $\mathrm{X} 2.4$ & 0,069 & Sangat Lemah \\
\hline 13 & $\mathrm{X} 2.5$ & $-0,136$ & Tidak Ada Hubungan \\
\hline 14 & $\mathrm{X} 2.6$ & $-0,236$ & Tidak Ada Hubungan \\
\hline 15 & $\times 2.7$ & $-0,115$ & Tidak Ada Hubungan \\
\hline 16 & X3.1 & 0,122 & Sangat Lemah \\
\hline 17 & $\mathrm{X} 3.2$ & 0,501 & Cukup Erat \\
\hline 18 & X3.3 & 0,432 & Cukup Erat \\
\hline 19 & $\mathrm{X} 3.4$ & $-0,145$ & Tidak Ada Hubungan \\
\hline 20 & X3.5 & $-0,134$ & Tidak Ada Hubungan \\
\hline 21 & $\mathrm{X} 4.1$ & $-0,077$ & Tidak Ada Hubungan \\
\hline 22 & $\mathrm{X} 4.2$ & $-0,162$ & Tidak Ada Hubungan \\
\hline 23 & $\mathrm{X} 4.3$ & $-0,380$ & Tidak Ada Hubungan \\
\hline 24 & $\mathrm{X} 4.4$ & $-0,121$ & Tidak Ada Hubungan \\
\hline 25 & $\times 5.1$ & $-0,059$ & Tidak Ada Hubungan \\
\hline 26 & $\times 5.2$ & $-0,079$ & Tidak Ada Hubungan \\
\hline 27 & $\times 5.3$ & 0,401 & Cukup Erat \\
\hline 28 & $\times 5.4$ & 0,316 & Rendah \\
\hline 29 & $\mathrm{X} 6.1$ & $-0,601$ & Tidak Ada Hubungan \\
\hline 30 & $\mathrm{X} 6.2$ & $-0,263$ & Tidak Ada Hubungan \\
\hline 31 & X6.3 & $-0,276$ & Tidak Ada Hubungan \\
\hline 32 & $X 6.4$ & 0,056 & Sangat Lemah \\
\hline
\end{tabular}

Sumber data primer 2018 
JIRS Volume XVI Nomor 1, April 2019

Analisa Deskriptif

Metode deskriptif adalah penelitian yang dilakukan untuk mengetahui keberadaan variabel mandiri, baik hanya pada satu variabel atau lebih (variabel yang berdiri sendiri) tanpa membuat perbandingan dan mencari hubungan variabel itu dengan variabelyang lain, Sugiyono(2009:35).
e-ISSN : 2655-2124 / ISSN : 1858-3695

Analisa ini bertujuan untuk menyimpulkan sub faktor mana yang paling berpengaruh berdasarkan faktor planning dan design, pengaruh kontrak, perubah-an peraturan kerja dari pemerintah, kondisi bawah tanah, kontraktor, pengaruh permintaan owner, pengaruh kejadian alam, dan peyebab lainnya. Hasilnya akan disusun dalam bentuk tabel distribusi.

Tabel 11. Hasil Rekapitulasi Analisis Deskriptif

\begin{tabular}{||c|c|c|c||}
\hline NO & Faktor-faktor yang mempengaruhi keuntungan kontraktor & Mean & $\begin{array}{c}\text { Persentase } \\
\%\end{array}$ \\
\hline 1 & $\begin{array}{c}\text { Kurang teliti dalam penggunaan material, sehingga ada } \\
\text { material konstruksi yang terpasang tidak sesuai dengan } \\
\text { rencana. (X1.3) }\end{array}$ & 4,77 & 95,4 \\
\hline 2 & $\begin{array}{c}\text { Tenaga kerja ceroboh dan tidak teliti, sehingga banyak } \\
\text { material yang terbuang-buang (X1.7) }\end{array}$ & 4,68 & 93,6 \\
\hline 3 & $\begin{array}{c}\text { Kurangnya optimalnya penjadwalan peralatan yang digunakan } \\
\text { sehingga mengakibatkan peralatan menggagur dalam jangka } \\
\text { waktu yang cukup lama (X3.2). }\end{array}$ & 4,09 \\
\hline 4 & $\begin{array}{c}\text { Penggunaan peralatan yang jarang dirawat atau peralatan } \\
\text { yang digunakan dalam keadaan tidak prima (X3.3). }\end{array}$ & 3,73 & 74,6 \\
\hline 5 & $\begin{array}{c}\text { Keterlambatan pencairan dana atau termyn yang } \\
\text { mengakibatkan pemimpin proyek harus berhutang (X5.3) }\end{array}$ & 4,27 & 85,4 \\
\hline
\end{tabular}

Sumber Hasil Analisis SPSS Versi 24

\section{PEMBAHASAN}

Sebelum penyebaran kuisioner penulis terlebih dahulu mengidentifikasikan faktor apa saja yang mempengaruhi keuntungan kontraktor pada proyek konstruksi gedung di kota padang, kemudian setelah penyebaran kuisioner selesai maka penulis melanjutkan untuk pengolahan data, yaitu uji validitas, reliabilitas, korelasi dan uji deskriptif. Dari hasil pengolahan analisis deskriptif yan telah penulis lakukan,dengan melihat nilai mean tertinggi yang memiliki hubungan dengan keuntungan kontraktor mewakili setiap variabel yang dianalisis, diperoleh hasil bahwa faktor-faktor yang mempengaruhi keuntungan kontraktor di kota Padang adalah varaibel faktor tenaga kerja sub variabel faktor kurang teliti dalam penggunaan material, sehingga ada material konstruksi yang terpasang tidak sesuai dengan rencana dengan nilai mean 4,77 , variabel faktor peralatan sub vaiabel faktor Kurangnya optimalnya penjadwalan peralatan yang digunakan sehingga mengakibatkan peralatan menggagur dalam jangka waktu yang cukup lama dengan nilai mean 4,09, variabel faktor keuangan dengan sub vaiabel faktor Keterlambatan pencairan dana atau termyn yang mengakibatkan pemimpin proyek harus berhutang dengan nilai mean 4,27 . Sedangkan faktor yang palig 
JIRS Volume XVI Nomor 1, April 2019

dominan yang mempengaruhi keuntungan kontraktor adalah Kurang teliti dalam penggunaan material, sehingga ada material konstruksi yang terpasang tidak sesuai dengan rencana yaitu dapat dilihat dengan nilai mean tertinggi dari 5 faktor yang mempengaruuhi keuntungan kontraktor pada proyek konstruksi di kota Padang.

1. Kurang teliti dalam penggunaan material, sehingga ada material konstruksi yang terpasang tidak sesuai dengan rencana

Pengelola material harus menjaga komunikasi yang baik dengan pelaksana proyek agar tidak terjadi kesalahan dalam pemesanan material yang dibutuhkan. Pengalokasian material yang optimal tidak hanya menghemat biaya tetapi juga mempercepat waktu pelaksanaan. Dengan membuat jadwal penggunaan material (Material Schedules) dapat dilihat besarnya penggunaan material yang direncanakan berdasarkan pekerjaan konstruksi yang akan dilaksanakan.

Contoh pada pekerjaa kuda-kuda kayu pada proyek gedung karena kurang ketelitian dari tukang yang memakai kayu kelas 1 sedangkan pada perencanaan yang telah disetujui memakai kayu kelas 2 hal ini menyebabkan kerugian terhadap kontraktor karena perbedaan harga antara kayu kelas satu dan kayu kelas dua lebih kurang satu juta rupiah per meter kubiknya.

2. Kurangnya optimalnya penjadwalan peralatan yang digunakan sehingga mengakibatkan peralatan menggagur dalam jangka waktu yang cukup lama

Pada pengerjaan proyek skala besar seperti gedung bertingkat, pengaspalan jalan, pembuatan landasan pesawat terbang, dan proyek besar lainnya,
e-ISSN : 2655-2124 / ISSN : 1858-3695

penggunaan alat berat sudah umum digunakan. Selain untuk mempercepat waktu pengerjaan, efisiensi dalam nilai ekonomi pun diperoleh dengan pemanfaatan alat berat. Penggunaan alat berat pada proyek konstruksi memiliki berbagai jenis sesuai dengan fungsi dan aplikasinya. Oleh karena itu, diperlukan sistem pengelolaan dan manajemen yang baik. Hal ini bertujuan agar pola efisiensi waktu, tenaga, serta teknik perawatan pada alat berat tersebut dapat berjalan dengan baik tanpa membroskan biaya yang tidak seharusnya dikeluarkan.

3. Keterlambatan pencairan dana atau termyn yang mengakibatkan pemimpin proyek harus berhutang

Dana atau uang adalah hal terpenting di dalam proyek konstruksi tanpa adanya uang atau modal maka proses pekerjaan tidak bisa dilaksankan karena pekerjaan konstruksi membutuhkan biaya operasional.

Keterlambatan pencairan dana dapat berakibat fatal karena dapat menunda semua pekerjaan konstruksi yang sedang dilaksanakan. Dan hal ini akan menyebabkan keterlambatan pada proyek konstruksi tersebut. Hal ini mempengaruhi keuntungan kontraktor karena semakin lama pekerjaan itu selesai maka semakin banyak pula biaya operasional yang dikeluarkan.

\section{Kesimpulan}

Berdasarkan penelitian yang telah dilakukan, maka penulis menyimpulkan sebagai berikut:

1. Variabel dalam penelitian ini terdiri dari 6 variabel yaitu variabel-variabel faktor yang mempengaruhi kentungan kontraktor pada proyek konstruksi di kota Padang sebagai 
variabel $X$ terdiri dari : Tenaga Kerja,

Material, Peralatan, Metode Pelaksanaan,

Keuangan, dan Karakteristik Lapangan.

Data-data yang didapatkan pada saat pengujian validitas semua data dinyatakan valid dan juga semua data tersebut dapat dipercaya/reliabilitas dimana tujuan pengujian realiabilitas ini adalah melihat kekonsistenan jawaban seseorang terhadap pernyataan dari waktu ke waktu. Berikut faktor-faktor yang mempengaruhi keuntungan kontrakor pada proyek konstruksi di kota Padang berdasarkan hasil uji deskriptif yang memiliki nilai mean tertinggi, yaitu :

a. Kurang teliti dalam penggunaan material, sehingga ada material konstruksi yang terpasang tidak sesuai dengan rencana pada variabel tenaga kerja dimana faktor ini sangat mempengaruhi keuntungan kontraktor pada proyek konstruksi gedung di kota Padang karena memiliki persentase $95,4 \%$. Hal ini terjadi karena pada saat pengerjaan tidak adanya pengawasan yang baik dari seorang site manager sehingga tukang atau pun pekerja memakai material yang ada di lapangan secara sembarangan. Contohnya pada pekerjaan sanitair yang seharusnya menggunakan closet jongkok merk ina karena kurangnya pengawsan dari site manager tukang memakai closet jongkok ber merk american standartsehingga faktor ini sangat mempengaruhi keuntungan dari kontraktor.

b. Tenaga kerja ceroboh dan tidak teliti, sehingga banyak material yang terbuangbuang pada variabel tenaga kerja faktor ini sangat mem-pengaruhi keuntungan kontraktor pada proyek konstruksi gedung di kota Padang karena memiliki persentase
93,6\%. Hal ini terjadi karena tukang dan pekerja yang kurang cakap ketika bekerja. Ketika musim proyek mencari tukang dan pekerja yang handal sangat sulit, kebanyakan tukang dan pekerja yang ada adalah petani yang menjadikan profesi tukang sebagai profesi sampingan sambil menunggu musim panen datang, Kekbanyakan dari mereka tidak memiliki pengalaman yang memadai.

c. Kurangnya optimalnya penjadwalan peralatan yang digunakan sehingga mengakibatkan peralatan menggagur dalam jangka waktu yang cukup lama Kurangnya optimalnya penjadwalan peralatan yang digunakan sehingga mengakibatkan peralatan menggagur dalam jangka waktu yang cukup lama pada variabel peralatan faktor ini mempengaruhi keuntungan kontraktor pada proyek konstruksi gedung di kota Padang karena memiliki persentase $81,8 \%$. Hal ini karena perencanaan dari project manager yang kurang baik, perencanaan jadwal peralatan yang baik harus memperhatikan kondisi lapangan yang dihadapi sehigga penggunaan peralatan dapat di optimalkan.

d. Penggunaan peralatan yang jarang dirawat atau peralatan yang digunakan dalam keadaan tidak prima faktor ini mempengaruhi keuntungan kontraktor pada proyek konstruksi gedung di kota Padang karena memiliki persentase $74,6 \%$. Peralatan yang baik akann menunjang pekerjaan dengan baik. Peralatan yang tidak terawat akan membuat produktifitas menurun dan hal itu akan membuat proses pekerjaan jadi lebih lama selesai dan ini akan mempengaruhi keuntungan kontraktor. 
JIRS Volume XVI Nomor 1, April 2019

e. Keterlambatan pencairan dana atau termyn yang mengakibatkan pemimpin proyek harus berhutang faktor ini mempengaruhi keuntungan kontraktor pada proyek konstruksi gedung di kota Padang karena memiliki persentase $85,4 \%$. Modal usaha sangat diperlukan untuk kelancaran pekerjaan dengan adanya modal usaha terlambatnya pencairan termyn tak akan mempengaruhi proses pekerjaan konstruksi

2. Dari enam subfaktor yang mempengaruhi keuntungan kontraktor pada proyek konstruksi gedung, terdapat subfaktor yang dominan yaitu pada subfaktor Tenaga kerja ceroboh dan tidak teliti, sehingga banyak material yang terbuang-buang pada variabel tenaga kerja. Ini membuktikan faktor tersebut sangat berpengaruh terhadap keuntungan kontraktor.

3. Pada subfaktor Tenaga kerja ceroboh dan tidak teliti, sehingga banyak material yang terbuang-buang pada variabel tenaga kerja didapatkan hajil uji deskriptif yaitu sebesar $95,4 \%$ serta nilai person korelasi 0,582 berada pada rentang 0,400-0,599 ini menyatakan hubungan antara subfaktor penyebab dan dengan keuntungan kontraktor adalah cukup kuat dengan nilai signifikannya sebesar 0,004 0,05 yang disyaratkan.

\section{Saran}

1. Dengan mengetahui faktor-faktor yang mempengaruhi keuntungan kontraktor pada proyek konstruksi gedung di kota Padang. Penelitian ini diharapkan dapat
e-ISSN : 2655-2124 / ISSN : 1858-3695

memberikan masukan kepada pelaku jasa konstruksi (kontraktor) agar dapat dijadikan sebagai pedoman untuk memaksimlakan keuntungan perusahaan.

2. Untuk memaksimalkan keuntungan kontraktor sebaikanya setiap pekerjaan yang dilaksanakan harus diawasi dengan baik, dan sebelum memulai suatu pekerjaan tukang dan pekerja harus diberitahu tentang material-material apa saja yang akan digunakan dan diajarkan bagaimana cara pemasangan atau penggunaan material dengan baik dan benar.

\section{Daftar Pustaka}

Nata. Hendra, dkk, Juni 2016. Faktor-Faktor Yang Mempengaruhi Profit Kontraktor Pada Proyek Konstruksi.

Susila. Herman, Handoyo. Suryo, 2015. Analisis Faktor Dominan Resiko Biaya Pada Pelaksanaan Proyek Konstruksi Gedung Di Surakarta.

Kaming. Peter F, dkk, Oktober 2014. Strategi Penetapan Harga Proyek Oleh Kontraktor Yokyakarta

Santoso. Indriani, 2014. Analisis Overruns Biaya Pada Beberapa Tipe Proyek Konstruksi.

Devin. Rafael, dkk, 2014. Analisis Biaya Preliminaries Proyek Bangunan Gedung Bertingkat (Studi Pada Perusahaan Kontraktor $X$ ).

Lantang. Fharel Novel, dkk, Februari 2014. Perencanaan Biaya Dengan Menggunakan Perhitungan Biaya Nyata Pada Proyek Perumahan (Studi Kasus Perumahan Green Hill Residence)

Imam Soeharto, Ir. 1995. Manajemen Proyek Dari Konseptual Sampai Operasional. Diterbitkan Oleh Penerbit Erlangga Jakarta. 